\title{
IMPLIKASI PERUMUSAN DELIK KORUPSI DI DALAM KEBIJAKAN PEMBAHARUAN KITAB UNDANG- UNDANG HUKUM PIDANA
}

\section{Implications of Corruption Offense Formulation in Renewal Policies of the Criminal Code}

\author{
Syaputra \\ Universitas Gadjah Mada, Yogyakarta \\ email: actnow300889@gmail.com
}

\begin{abstract}
The Criminal Code as a legacy of Dutch colonialism could no longer follow the dynamism of community life. It is too rigid has obliterated the sense of justice which is the goal of the creation of the law itself. This is because the articles of the Criminal Code deemed unsuitable to the development of crime and offenses increasingly complex. In the draft Code of Criminal Law, as one of the reform effort is the formulation of offenses of corruption set out in Chapter XXXII starting from Article 688 to Article 702. With the formulation of the offense of corruption and offenses positions formulated in the draft Criminal Code will disregard the Law Combating Corruption although this law of particular importance because of the substance of the articles draft Criminal Code wants to make corruption has become common crimes and do not pass through handling extraordinary. Law on Corruption Eradication cannot apply even if there is the principle of lex specialis derogat lex generalis, because of the retroactive principle that applies in the draft Criminal Code so that the decision to force the law can still be applied retroactively when the rule of law that new does not regulate the offense of criminal, so punishment can be eliminated.
\end{abstract}

Keywords: Offense Corruption, Corruption, Reform of draft Criminal Code

abstrak

KUHP sebagai warisan kolonialisme Belanda tidak dapat lagi mengikuti dinamisme kehidupan masyarakat. Sifatnya yang terlalu kaku telah melenyapkan rasa keadilan yang merupakan tujuan dari penciptaan hukum itu sendiri. Hal ini dikarenakan pasal-pasal dalam KUHP dianggap tidak sesuai lagi dengan perkembangan kejahatan dan pelanggaran yang semakin kompleks. Dalam Rancangan Kitab Undang-Undang Hukum Pidana, sebagai salah satu upaya pembaharuan adalah adanya perumusan delik-delik tentang korupsi yang diatur di dalam Bab XXXII dimulai dari Pasal 688 sampai dengan Pasal 702. Dengan adanya rumusan delik korupsi dan delik jabatan 
yang dirumuskan dalam RKHUP akan mengenyampingkan Undang-Undang Pemberantasan Tindak Korupsi meskipun undang-undang ini sifatnya khusus karena substansi pasal-pasal RKHUP sifatnya ingin membuat tindak pidana korupsi tersebut menjadi tindak pidana umum dan tidak melewati penanganan yang luar biasa. Undang-Undang Pemberantasan Tindak Pidana Korupsi tidak dapat berlaku meskipun ada asas lex spesialis derogat lex generalis, karena adanya asas retroaktif yang berlaku dalam RKHUP sehingga terhadap putusan yang kekuatan hukumnya tetap dapat berlaku surut ketika dalam peraturan undang-undang yang baru tidak mengatur delik pidananya, sehingga pemidanaannya dapat dihapuskan.

\section{Kata Kunci: Delik Korupsi, Korupsi, Pembaharuan RKUHP}

\section{A. Pendahuluan}

Kitab Undang-Undang Hukum Pidana merupakan induk hukum pidana di Indonesia, dalam bahasa belandanya disebut Wetboek van Strafrecht. Artinya KUHP merupakan peninggalan penjajahan Belanda yang sampai sekarang masih digunakan. Pemberlakuan KUHP di indonesia dimulai dengan adanya Koninklijk Besluit (titah raja) untuk memberlakukan Wetboek van Strafrecht voor Nederlandsch Indie di Indonesia sebagai turunan dari WvS Belanda pada januari 1918. ${ }^{1}$

Pemerintah kolonial Belanda pada saat itu menerapkan asas konkordansi bagi pemberlakuan WvS di negara jajahannya. Beberapa pasal dihapuskan dan disesuaikan dengan kondisi dan misi kolonialisme Belanda atas wilayah indonesia.

Setelah Indonesia menyatakan kemerdekaannya pada tahun 1945, untuk mengisi kekosongan hukum pidana, pemerintah Indonesia tetap memberlakukan WvSvNI dengan dasar Pasal II Aturan Peralihan UUD 1945 yang kemudian lahirlah Undang-Undang Nomor 1 Tahun 1946 Tentang Peraturan Hukum Pidana.

Pemberlakuan Kitab Undang-Undang di seluruh wilayah Republik Indonesia atau nasional baru dilakukan pada tanggal 20 September 1958, dengan diundangkannya UU No. 73 Tahun 1958 tentang Menyatakan Berlakunya Undang-Undang No. 1 Tahun 1946 Republik Indonesia tentang Peraturan Hukum Pidana Untuk Seluruh Wilayah Republik Indonesia dan Mengubah Kitab Undang-Undang Hukum Pidana. Sebagaimana yang dinyatakan dalam Pasal 1 yang berbunyi, "Undang-Undang No. 1 tahun

\footnotetext{
${ }^{1}$ http://hukumpidana.bphn.go.id/sejarah-kuhp/, diakses pada 23 September 2014, Pukul 02:18 WIB.
} 
1946 Republik Indonesia tentang Peraturan Hukum Pidana dinyatakan berlaku untuk seluruh wilayah Republik Indonesia."2

KUHP sebagai warisan kolonialisme Belanda tidak dapat lagi mengikuti dinamisme kehidupan masyarakat. Sifatnya yang terlalu kaku telah melenyapkan rasa keadilan yang merupakan tujuan dari penciptaan hukum itu sendiri. Hal ini dikarenakan pasal-pasal dalam KUHP dianggap tidak sesuai lagi dengan perkembangan kejahatan dan pelanggaran yang semakin kompleks.

Untuk menanggulangi hal tersebut, dibuatlah aturan yang lebih khusus dan sistematis terhadap perkembangan kejahatan dan pelanggaran, terutama yang sifatnya luar biasa. Dengan alasan bahwa aturan yang lebih khusus dan sistematis tersebut dapat membantu dan melindungi KUHP dari perkembangan tindak pidana yang lebih kompleks.

Namun, ketentuan dalam aturan khusus mengenai rumusan norma pidana, sanksi pidana dan acara pidana memuat kaedah hukum yang menyimpang dari ketentuan umum hukum pidana, baik pidana materiil maupun pidana formil sehingga terjadi penumpukkan norma pidana dan sanksi pidana. implikasinya, memunculkan sistem perumusan norma pidana dan sistem perumusan ancaman sanksi pidana menjadi Dual System. ${ }^{3}$

Dengan alasan adanya Dual System tersebut, pembaharuan hukum pidana sangat diperlukan dan harus dilakukan secara menyeluruh dengan tujuan agar tidak terjadi disparitas terhadap upaya penanggulangan maupun penegakkan hukum pidana sehingga materi hukum pidana yang dilakukan dengan ekstra hati-hati, yaitu dengan memperhatikan konteks masyarakat di mana hukum pidana itu diberlakukan dan tetap menjunjung tinggi nilai-nilai kemanusiaan yang beradab.

Dalam Rancangan Kitab Undang-Undang Hukum Pidana, sebagai salah satu upaya pembaharuan adalah adanya perumusan delik-delik tentang korupsi yang diatur di dalam Bab XXXII dimulai dari Pasal 688 sampai dengan Pasal 702.

Pembahasan terhadap rumusan pasal-pasal tersebut banyak memunculkan permasalahan terutama pada penanggulangan dan penegakkannya yang dianggap bahwa tindak pidana korupsi yang sifatnya

\footnotetext{
${ }^{2}$ Pasal 1 Undang-Undang No. 73 Tahun 1958 tentang Menyatakan Berlakunya UndangUndang No. 1 Tahun 1946 Republik Indonesia tentang Peraturan Hukum Pidana Untuk Seluruh Wilayah Republik Indonesia dan Mengubah Kitab Undang-Undang Hukum Pidana.

${ }^{3}$ Mudzakkir, Model dan Kebijakan Kodifikasi Serta Perumusan Delik Korupsi dalam RKUHP, dalam Focus Group Discussion dengan tema "Pengaturan Delik Korupsi dan Implikasi Hukumnya terhadap Praktik Pemberantasan Korupsi di Indonesia" yang diselengarakan oleh Komisi Pemberantasan Korupsi (KPK) di Hotel Grand Cokro, Yogyakarta, 08 Oktober 2013.
} 
khusus dan merupakan Extra Ordinary Crime menjadi tindak pidana umum dan/atau tindak pidana biasa.

Apabila delik korupsi masuk dalam Rancangan Kitab Undang-Undang Hukum Pidana maka tindak pidana korupsi akan kehilangan sifat kekhususan yang berdampak pada pola penanganan perkara. Artinya akan menghilangkan sifat tindak pidana korupsi sebagai "kejahatan luar biasa", menjadi kejahatan biasa. penanganan tindak pidana korupsi termasuk kewenangan pemeriksaan tipikor, dalam proses penyelidikan, penyidikan dan penuntutan bukan lagi ranah KPK. Bahkan juga Jaksa Tindak Pidana Khusus. Penanganan korupsi akan sepenuhnya menjadi kewenangan polisi.

Rancangan Kitab Undang-Undang Hukum Pidana merupakan salah satu produk hukum yang luar biasa bagi bangsa di Indonesia. Apabila kelak disetujui, untuk pertama kalinya setelah 70 tahun Indonesia merdeka yang memiliki Undang-Undang Hukum Pidana buatan sendiri. Hal ini bukan berarti produk hukum tersebut merupakan suatu cara untuk mengorbankan semangat pemberantasan korupsi. Sebelum membahas Rancangan Kitab Undang-Undang Hukum Pidana, Pemerintah dan DPR mesti mengingat kembali bahwa korupsi sampai saat ini masih menjadi kejahatan yang sangat mengancam. ${ }^{4}$

Dari latar belakang yang telah diuraikan diatas maka munculah permasalahan yang akan dibahas, yaitu apakah pengaturan tindak pidana korupsi di dalam RKUHP akan melemahkan sifat luar bisa UU No.20 tahun 2001 tentang tindak pidana korupsi sebagai delik khusus?

Metode penelitian yang digunakan adalah metode normatif, yaitu menggunakan metode kepustakaan yang terdiri dari buku-buku hukum yang berkaitan dengan isu hukum tersebut, kemudian peraturan perundangundang serta bahan-bahan sekunder lainnya yang berkaitan dengan hal tersebut.

\section{B. Pembahasan}

\section{Kebijakan Pembaharuan Hukum Pidana}

Pengaturan tentang tindak pidana korupsi berawal dari peraturan penguasa perang pusat pada tahun 1957 yang dikeluarkan berdasarkan UU Darurat. Setahun kemudian peraturan tersebut diganti karena UU Darurat yang mendasarinya juga berakhir masa berlakunya. Namun setelah itu pengaturan tindak pidana korupsi, tetap konsisten diatur dalam UU tersendiri hingga pengaturan dengan UU yang sekarang. Ini menunjukkan bahwa pandangan masyarakat terhadap tindak pidana korupsi sejak pertengahan

\footnotetext{
4 RKUHP, korupsi bukan lagi kejahatan luar biasa dalam https://beritagar.id/artikel/editorial/ruu-kuhp-korupsi-bukan-lagi-kejahatan-luar-biasa, diakses pada tanggal 8 April 2016 pukul 14:08 WIB.
} 
tahun 50-an tersebut hingga sekarang tetap sama, bahwa tindak pidana ini termasuk tindak pidana serius yang membutuhkan pengaturan tersendiri pula untuk menanggulanginya. ${ }^{5}$

Pembaharuan hukum pidana pada hakekatnya mengandung makna, suatu upaya untuk melakukan reorientasi dan reformasi hukum pidana yang sesuai dengan nilai-nilai sentral sosiopolitik, sosiofilosofis, dan sosiokultural masyarakat Indonesia yang melandasi kebijakan sosial, kebijakan kriminal, dan kebijakan penegakkan hukum di Indonesia.

Secara singkat dapatlah dikatakan, bahwa pembaharuan hukum pidana pada hakikatnya harus ditempuh dengan pendekatan yang berorientasi pada kebijakan (policy oriented approach) dan sekaligus pendekatan yang berorientasi pada nilai (value oriented approach). ${ }^{6}$

a. Policy Oriented Approach ${ }^{7}$

1) Sebagai bagian dari kebijakan sosial, pembaharuan hukum pidana pada hakikatnya merupakan bagian dari uupaya untuk mengatasi masalahmasalah sosial (termasuk masalah kemanusiaan) dalam rangka mencapai/menunjang tujuan nasional (kesejahteraan masyarakat dan sebagainya).

2) Sebagai bagian dari kebijakan kriminal, pembaharuan hukum pidana pada hakikatnya merupakan bagian dari upaya perlindungan masyarakat (khususnya upaya penanggulangan kejahatan).

3) Sebagai bagian dari kebijakan penegakan hukum, pembaharuan hukum pidana pada hakikatnya merupakan bagian dari upaya memperbarui substansi hukum (legal substance) dalam rangka lebih mengefektifkan penegakan hukum.

b. Value Oriented Approach ${ }^{8}$

Pembaharuan hukum pidana pada hakikatnya merupakan upaya melakukan peninjauan dan penilaian kembali nilai-nilai sosiopolitik, sosiofilosofis, dan sosiokultural yang melandasi dan memberi isi terhadap muatan normatif dan substantif hukum pidana yang dicita-citakan. Bukanlah pembaharuan hukum piidana, apabila orientasi nilai dari hukum pidana yang dicita-citakan sama saja dengan orientasi nilai dari hukum pidana warisan penjajah.

Ketentuan- ketentuan tindak pidana korupsi yang terdapat dalam KUHP dirasa kurang efektif dalam mengantisipasi atau bahkan mengatasi permasalahan tindak pidana korupsi. Oleh karena itu, dibentuklah suatu

\footnotetext{
${ }^{5}$ Andi Hamzah. Pemberantasan Korupsi Melalui Hukum Pidana Nasional dan Internasional. (Jakarta: Rajagrafindo Persada, 2006), hlm. 10.

${ }^{6}$ Barda Nawawi Arief, 2010, Bunga Rampai Kebijakan Hukum Pidana Perkembangan Penysunan Konsep Kuhp Baru, Kencana: Jakara, hlm. 29.

${ }^{7}$ Ibid.

${ }^{8}$ Ibid, hlm. 30.
} 
peraturan perundangundangan guna memberantas masalah korupsi, dengan harapan dapat mengisis serta menyempurnakan kekurangan yang terdapat pada KUHP. Dengan berlakunya Undang- Undang 20 Tahun 2001 tentang Perubahan atas Undang-Undang Nomor 31 Tahun 1991 tentang Pemberantasan tindak Pidana korupsi, maka ketentuan Pasal 209 KUHP, Pasal 210 KUHP, Pasal 387 KUHP, Pasal 388 KUHP, Pasal 415, Pasal 416 KUHP, Pasal 417 KUHP, Pasal 418 KUHP, Pasal 419 KUHP, Pasal 420 KUHP, Pasal 423 KUHP, Pasal 425 KUHP, Pasal 434 KUHP dinyatakan tidak berlaku. ${ }^{9}$

Jika ditinjau dari instrumen hukumnya, Indonesia telah memiliki banyak peraturan perundang- undangan untuk mengatur pemberantasan tindak pidana korupsi. Diantaranya ada KUHP, Undang- Undang Nomor 31 Tahun 1999 tentang pemberantasan tindak pidana korupsi beserta revisinya melalui Undang- Undang Nomor 20 tahun 2001, bahkan sudah ada Komisi Pemberantasan Tindak Pidana Korupsi (KPK) yang dibentuk berdasarkan Undang- Undang Nomor 30 Tahun 2002. Secara substansi Undang- undang Nomor 31 Tahun 1999 telah mengatur berbagai aspek yang kiranya dapat menjerat berbagai modus operandi tindak pidana korupsi yang semakin rumit.

2. Implikasi Pengaturan Delik Korupsi di dalam RKUHP

a. Terhadap Kekuatan Undang-Undang Nomor 31 Tahun 1999 jo Undang-Undang Nomor 20 Tahun 2001 tentang Tindak Pidana Korupsi

Delik korupsi yang dimasukkan ke dalam RKUHP bukan lagi digolongkan kejahatan luar biasa sebagaimana tindak pidana tertentu yang dianggap serius, seperti tindak pidana terorisme dan tindak pidana pencucian uang yang dalam RKUHP memperluas hal dapat dipidananya suatu percobaan sampai kepada perbuatan persiapan. Hal ini tidak berlaku untuk tindak pidana korupsi, padahal ketentuan pasal 27 (1) UNCAC mengamanatkan hal tersebut.

Sesuai ketentuan Pasal 22 RKUHP, pidana untuk pembantuan, termasuk pembantuan delik korupsi diancam dengan pidana maksimum dikurangi sepertiga, padahal jelas dalam Undang-Undang Tindak Pidana Korupsi ditentukan bahwa ancaman pidana untuk pembantuan sama dengan ancaman pidana untuk pelaku.

Mengenai rumusan delik korupsi dalam RKUHP, bahwa yang termasuk dalam delik koruptif itu adalah delik jabatan, delik korupsi dan delik perbuatan curang. Namun Jika dicermati, substansi dari pasal-pasal

9 http://repository.usu.ac.id/bitstream/123456789/31169/3/Chapter\%20II.pdf diakses pada tanggal 8 April 2016. 
yang terdapat di dalam RKUHP yang dirumuskan hanya memaparkan unsurunsur delik saja, tanpa menyebutkan kualifikasi juridisnya. Di dalam substansi dari pasal-pasal itu juga tidak merumuskan prinsip-prinsip dasar tentang kesalahan yang berupa kesengajaan (dolus) dan kelalaian (culpa) yang seharusnya dijadikan sebagai unsur subjektif dalam suatu peristiwa, perbuatan atau tindak pidana. Prinsip dasar inilah yang diperlukan untuk menentukan apakah seseorang yang melakukan tindak pidana dapat dimintai pertanggungjawaban pidana kepadanya (toerekeningsvatbaarheid) atau perbuatannya tersebut dapat dikategorikan sebagai ketidak-mampuan bertanggungjawab (on toerekeningsvatbaarheid).

Di lain pihak, asas strict liability dan vicarious liability tidak dapat diterapkan, khususnya kepada korporasi yang melakukan tindak pidana korupsi karena dalam substansi pasal-pasal dalam RKUHP secara tegas tidak mengatur bagaimana diterapkannya konsep pertanggungjawaban tersebut.

RKUHP tidak lagi mengenal pidana pembayaran uang pengganti sebagaimana yang diketahui dalam Pasal 18 ayat (1) butir b UndangUndang Tentang Tindak Pidana Korupsi, padahal keberadaan jenis pidana tersebut merupakan satu hal yang esensial dalam konteks mengembalikan kerugian keuangan negara.

Karena tidak adanya unsur subyektif terjadinya suatu delik yang terkandung dalam pasal-pasal tersebut, akan berimplikasi terhadap upaya penegakkannya (application) dimana unsur kesalahan yang berupa kesengajaan, kelalaian dan perbuatan melawan hukum sulit untuk dibuktikan sehingga tidak dapat dimintai pertanggungjawabannya.

Oleh karena itu, rumusan delik-delik korupsi dalam RKUHP yang sifatnya telah menjadi delik umum akan melemahkan bahkan mampu menghapuskan kekuatan dan kepastian hukum yang ada dalam UU No. 31 Tahun 1999 jo UU no. 20 Tahun 2001 karena dalam prinsipnya jika ada perubahan dalam perundang-undangan sesudah perbuatan di lakukan, maka dapat diterapkan ketentuan yang paling menguntungkan baginya. ${ }^{10}$

Alasan lainnya adalah tindak pidana korupsi yang diatur dalam RKUHP tidak lagi memuat unsur kerugian negara sebagaimana dalam pasal 2 dan pasal 3 Undang-Undang Nomor 31 Tahun 1999 jo Undang-Undang Nomor 20 Tahun 2001. Terkait dengan adanya prinsip dasar/asas retroaktif yang terkandung dalam pasal 2 RKUHP, memberikan celah untuk menyurutkan sanksi pidana ganti kerugian keuangan negara tersebut, dan pada akhirnya akan menghilangkan eksistensi kekuatan dan kepastian hukumnya.

${ }^{10}$ Pasal 2 Rancangan Kitab Undang-Undang Hukum Pidana 
Adapun di dalam naskah akademik RKUHP, kriteria yang digunakan untuk menempatkan ketentuan pidana di dalam RKUHP, adalah: ${ }^{11}$

a. Merupakan perbuatan jahat yang independen (tidak mengacu atau tergantung pada pelanggaran terlebih dahulu terhadap ketentuan hukum administrasi dalam peraturan perundang-undangan)

b. Daya berlakunya relative lestari (tidak dikaitkan dengan berlakunya prosedur atau proses administrasi)

c. Ancaman hukumannya lebih dari 1 tahunpidana perampasan kemerdekaan.

Bila mencermatikriteriapertama, tentang perbuatan jahat yang independen, maka tindak pidana korupsi sebagaimana diatur dalam pasal 2 dan pasal 3 UU Tipikor tidak memenuhi syarat tersebut, karena syarat melawan hukum pada ke dua pasal tersebut pada umumnya bersumber pada bidang hukum adminstrasi. Sangat boleh jadi, atas pertimbangan tersebut maka pada awalnya ${ }^{12}$, tindak pidana korupsi tidak ditemukan sebagai salah satu delik yang dimasukan dalam RKUHP.

Pengaturan tindak pidana korupsi dikembalikan lagi ke dalam RKUHP, demikian juga tindak pidana korupsi yang inti dengan rumusan tindak pidana korupsi yang telah disesuaikan dengan perkembangan pengaturan tindak pidana korupsi dan perkembangan internasional tentang pemberantasan tindak pidana korupsi dan praktek penegakan hukumnya. Hal ini dilakukan untuk menyesuaikan perkembangan hukum pidana menuju kepada standarisasi penyusunan norma hukum pidana dan pengancaman sanksi pidana serta menghindari sifat eksepsionalitas atau kesemntaraan hukum pidana. ${ }^{13}$

\section{b. Penanganan Terhadap Tindak Pidana Korupsi Oleh Komisi Pemberantasan Korupsi}

Rumusan delik dalam RKUHP pada Bab XXXI mengatur tentang tindak pidana jabatan, pegawai negeri dan hakim yang menerima suap serta penyalahgunaan kekuasaan. Jelas bahwa delik ini diletakkan diluar Bab XXXII Tentang Tindak Pidana Korupsi yang seharusnya delik ini pada dasarnya lebih tepat dimasukkan ke dalam Bab tentang korupsi. Dengan demikian, jika RKUHP ini berlaku maka KPK dan Pengadilan Tipikor hanya berwenang melakukan proses hukum terhadap tindak pidana korupsi saja.

Pada Bab III Undang-Undang Pemberantasan Tindak Pidanan Korupsi mengatur tindk pidana lain yang berkaitan dengan tindak pidana korupsi

\footnotetext{
${ }^{11} \mathrm{http} / / /$ www.antikorupsi.org/sites/antikorupsi.org/files/doc/Regulasi/NARASI\%20 Power\% 20Point-Agustinus\%20Pohan.pdf diakses pada tanggal 8 April 2016 pukul 16:45 WIB.

${ }^{12}$ Naskah Akademik Rancangan Kitab Undang-undang Hukum Pidana, hlm. 144.

${ }^{13}$ Ibid., hlm. 246.
} 
yang dikenal sebagai tindak pidana menghalang-halangi proses peradilan (obstruction of justice). ${ }^{14}$ Dalam RKHUP juga meumuskan tindak pidana menghalang-halangi proses peradilan, namun sifatnya umum dan terletak di luar Bab tentang tindak pidana korupsi.

Konsekuensinya, tindak pidana menghalang-halangi proses peradilan dalam perkara tindak pidana korupsi dipandang sama dengan tindak pidana menghalang-halangi proses peradilan dalam perkara tindak pidana lainnya, sehingga proses peradilannyapun menggunakan peradilan umum. Maka dari itu, kewenangan KPK dan Pengadilan Tindak Pidana Korupsi terhadap tindak pidana tersebut hilang karena kewenangan tersebut menjadi kewenangan penegak hukum umum.

Dalam pembahasan sebelumnya dikatakan bahwa RKHUP tidak memasukkan model korupsi pada pasal 2 dan 3 Undang-Undang Pemberantasan Tindak Pidana Korupsi mengenai perbuatan terkait merugikan keuangan negara, sehingga fungsi KPK sesuai dengan isi Pasal 6 huruf c akan terkikis, jika RKUHP diberlakukan.

RKUHP tidak memuat perumusan tindak pidana korupsi sebagaimana diatur dalam pasal 2 dan pasal 3 UU Tipikor. Harus diakui bahwa perumusan pasal 2 dan pasal 3 merupakan perumusan yang cenderung dapat ditafsirkan secara luas. Namun bila semata-mata hanya karena pertimbangan tersebut ke dua pasal tersebut dihapuskan, maka sukar dapat diterima. Ke dua pasal tersebut merupakan bagian dari sejarah pemberantasan korupsi di Indonesia dan merupakan pasal yang dibuat untuk mengatasi keadaan yang khas di Indonesia yang sangat mungkin tidak ditemukan dinegara lain. Korupsi di Indonesia tidak identik dengan suap/bribery sebagaimana pada umumnya di negara lain. Korupsi di Indonesia adalah soalkerugiannegara. Hal ini sesungguhnya diakui oleh penyusunnaskahakademiksebgaimanadinyatakan bahwa "Tindak pidana yang merugikan keuangannegaraialah tindak pidana korupsi". ${ }^{15}$

KPK dan Pengadilan ad hoc Tindak Pidana Korupsi dalam penegakan tindak pidana korupsi diatur dalam UU Tipikor, yang dengan sendirinya memberikan kewenangan kepada semua lembaga yang memiliki kewenangan dalam penyelidikan dan penyidikan tindak pidana korupsi untuk menanganinya. Penempatan KPK dan Pengadilan ad hoc Tindak Pidana Korupsi sebagai tindak pidana yang berdiri sendiri dalam RKUHP, bukanlah merupakan hal yang keliru, bahkan secara akademik merupakan hal yang tepat. Problemnya adalah berkaitan dengan kewenangan dari lembaga yang dapat menangani KPK dan Pengadilan ad hoc Tindak Pidana Korupsi yang terjadi dalam pemberantasan tindak pidana korupsi, dengan

\footnotetext{
${ }^{14}$ Pasal 21 sampai dan Pasal 24 Bab III Undang-Undang Nomor 31 Tahun 1999 jo UndangUndang Nomor 20 Tahun 2001 Tentang Pemberantasan Tindak Pidana Korupsi.

${ }^{15}$ Naskah Akademik RKUHP, hlm. 245.
} 
mengingat adanya tiga lembaga yang berwenangan dalam hal tersebut. Dalam hal ini apakah RKUHP bermaksud untuk menyerahkanseluruh kewenangan dalam penyelidikan dan penyidikan KPK dan Pengadilan ad hoc Tindak Pidana Korupsi dalam pemberantasan tindak pidana korupsi kepada penyelidik/penyidik POLRI. Pada hemat saya dengan pertimbanganefisiensi, maka kewenangan menangani KPK dan Pengadilan ad hoc Tindak Pidana Korupsi yang terjadi dalam penegakan tindak pidana korupsi, diserahkan kepada lembaga yang sedang menangani penegakan tindak pidana korupsi terkait. ${ }^{16}$

KPK dan Pengadilan ad hoc Tindak Pidana Korupsi dapat dihapuskan ketika Undang-Undang Tentang Pemberantasan Tindak Pidana Korupsi kekuatan dan kepastian hukumnya mulai menyurut, karena pada dasarnya undang undang ini lebih menitikberatkan pada perlindungan terhadap kerugian keuangan negara.

\section{Penutup}

\section{Simpulan}

Berdasarkan pembahasan sebelumnya, maka dapat ditarik kesimpulan bahwa RKHUP akan melemahkan Undang-Undang Pemberantasan Tindak Korupsi meskipun undang-undang ini sifatnya khusus karena substansi pasal-pasal RKHUP sifatnya ingin membuat tindak pidana korupsi tersebut menjadi tindak pidana umum dan tidak melewati penanganan yang luar biasa, karena RKUHP tidak memuat unsur kerugian negara sebagaimana dalam pasal 2 dan pasal 3 Undang-Undang Nomor 31 Tahun 1999 jo Undang-Undang Nomor 20 Tahun 2001. Terkait dengan adanya prinsip dasar/asas retroaktif yang terkandung dalam pasal 2 RKUHP, memberikan celah untuk menyurutkan sanksi pidana ganti kerugian keuangan negara tersebut, dan pada akhirnya akan menghilangkan eksistensi kekuatan dan kepastian hukumnya.

\section{Saran}

Pemerintah diharapkan agar mengeluarkan delik korupsi dan delikdelik lain yang termasuk dalam tindak pidana luar biasa dari RKUHP. Pemerintah dan DPR harus membahas RKUHP secara transparan dan akuntabel dengan melibatkan pihak-pihak terkait yang berkepentingan; dan Pemerintah dan DPR perlu mempercepat pembahasan RUU Tipikor yang memperkuat upaya pemberantasan korupsi dan kewenangan KPK.

\footnotetext{
${ }^{16} \mathrm{http} / / /$ www.antikorupsi.org/sites/antikorupsi.org/files/doc/Regulasi/NARASI\%20 Power\% 20Point-Agustinus\%20Pohan.pdf diakses pada tanggal 8 April 2016 pukul 17.04 WIB.
} 


\section{Daftar Pustaka}

\section{A. Buku}

Arief, Barda Nawawi, 2010, Bunga Rampai Kebijakan Hukum Pidana Perkembangan Penysunan Konsep KUHP Baru, Kencana: Jakara. , 2003, Kapita Selekta Hukum Pidana, Citra Aditya Bakti: Bandung.

, 2005, Beberapa Aspek Kebijakan Penegakan Dan Pengembangan Hukum Pidana, Citra Aditya Bakti: Bandung. 2008, Masalah Penegakan Hukum Dan Kebijakan Hukum Pidana Dalam Penanggulangan Kejahatan, Kencana: Jakarta.

Djaja, Ermansyah, 2009, Memberantas Korupsi Bersama Kpk: Kajian Yuridis Normatif UU Nomor 31 Tahun 1999 juncto UU Nomor 20 Tahun 2001 versi UU Nomor 30 Tahun 2002, Sinar Grafika: Jakarta

Hiariej, Eddy O. S., Dkk, 2006, Bunga Rampai Hukum Pidana Khusus, Pena Pundi Aksara: Jakarta,.

Moeljatno, 2008, Asas-Asas Hukum Pidana, Jakarta: Rineka Cipta.

Nurdjana, IGM, 2010, Sistem Hukum Pidana dan Bahaya Laten Korupsi "Perspektif Tegaknya Keadilan Melawan Mafia Hukum”, Pustaka Pelajar: Yogyakarta.

Rammelink, Jan, 2003, Hukum Pidana (Komentar Atas Pasal-Pasal Terpenting Dari Kitab Undang-Undang Hukum Pidana Belanda Dan Padanannya Dalam Kitab Undang-Undang Hhukum Pidana Indonesia), PT. Gramedia Pustaka Utama: Jakarta.

\section{B. Peraturan Perundang-Undangan}

Rancangan Kitab Undang-Undang Hukum Pidana

Undang-Undang No. 73 Tahun 1958 tentang Menyatakan Berlakunya Undang-Undang No. 1 Tahun 1946 Republik Indonesia tentang Peraturan Hukum Pidana Untuk Seluruh Wilayah Republik Indonesia dan Mengubah Kitab Undang-Undang Hukum Pidana.

Undang-Undang Nomor 31 Tahun 1999 jo Undang-Undang Nomor 20 Tahun 2001 Tentang Pemberantasan Tindak Pidana Korupsi.

\section{Internet}

http://hukumpidana.bphn.go.id/sejarah-kuhp/, diakses pada 23 September 2014, Pukul 02:18 WIB.

http://kbbi.web.id/delik, diakses pada tanggal 26 September 2014, pukul 13.34 WIB. 


\section{Lain-lain}

Dr. Mudzakkir, S.H.,M.H, Model dan Kebijakan Kodifikasi Serta Perumusan Delik Korupsi dalam RKUHP, dalam Focus Group Discussion dengan tema "Pengaturan Delik Korupsi dan Implikasi Hukumnya terhadap Praktik Pemberantasan Korupsi di Indonesia" yang diselengarakan oleh Komisi Pemberantasan Korupsi (KPK) di Hotel Grand Cokro, Yogyakarta, 08 Oktober 2013. 